\title{
FIRST COLLECTION OF MICONIA TURQUINENSIS \\ (MELASTOMATACEAE: MICONIEAE) WITH FLOWERS, AND COMPARISON WITH M. REMOTIFLORA, A PUTATIVE CLOSE RELATIVE
}

\author{
Walter S. Judd \\ Department of Biology, 220 Bartram Hall, \\ and Florida Museum of Natural History \\ University of Florida \\ Gainesville, Florida 32611, U.S.A. \\ lyonia@ufl.edu
}

\author{
Eldis R. Bécquer \\ Jardín Botánico Nacional \\ Universidad de La Habana, Carr. "El Rocío" km 3.5 \\ Calabazar, Boyeros, CP19230, CUBA \\ pachyanthus@gmail.com
}

\author{
Lucas C. Majure \\ Department of Research, Conservation and Collections \\ Desert Botanical Garden, 1201 North Galvin Parkway \\ Phoenix, Arizona 85008, U.S.A. \\ Imajure@dbg.org
}

ABSTRACT

\begin{abstract}
Miconia turquinensis, a species previously known only from specimens with immature inflorescences (two collections, including the type), in vegetative condition (six other collections), or in fruit (three collections) is now known from flowering material collected by Fabian Michelangeli and the second author (among others) in the Sierra Maestra, near the summit of Pico Turquino, Cuba. A revised description of this species, including previously unknown floral characters, is presented, and the species is compared to M. remotiflora, also of the Sierra Maestra, and a putative close relative. The phylogenetic position of M. turquinensis within Miconia sect. Chaenopleura is confirmed morphologically, and M. remotiflora is placed in this section for the first time.
\end{abstract}

Key Words: Miconia turquinensis, Miconia remotifolia, Miconia acunae, Miconia sect. Chaenopleura, Miconieae, Melastomataceae, Cuba

\section{RESUMEN}

Miconia turquinensis, una especie conocida previamente de un espécimen con la inflorescencia inmadura (dos colecciones, incluyendo el tipo), en condición vegetativa (las otras seis colecciones), o con fruto (tres colecciones) ha sido recolectado en flor por Fabián Michelangeli y el segundo autor (entre otros) en la Sierra Maestra, cerca de la cima de Pico Turquino, Cuba. Se presenta la descripción revisada de esta especie de Miconia sect. Chaenopleura, incluyendo caracteres florales antes no conocidos, y la especie se compara con un posible pariente cercano, M. remotiflora, también de la Sierra Maestra. La posición filogenética de M. turquinensis dentro de Miconia sect. Chaenopleura se confirma morfológicamente, y M. remotiflora se ubica en esta sección por primera vez.

Miconia turquinensis Urb. \& Ekman (Miconieae: Melastomataceae) is a poorly collected species of Miconia sect. Chaenopleura (Rich. ex DC.) Hook. f. that is endemic to the cloud forests and subalpine thickets at or near the summit of Pico Turquino, the highest peak on Cuba (Urban 1925; Judd 2007). A recent collection (9 Nov 2013) of this species by Fabian Michelangeli (NY) and the second author (i.e., Michelangeli et al. 2226) from near the summit of Pico Turquino represents the first collection of this species with mature flowers-the species was previously known only from the type collection (Ekman 14535, with very immature inflorescences), six additional collections (Bisse \& Lippold HFC-18862, Ekman 5479, Ekman 14485, Ekman s.n., 20 Jul 1922, and Bro. León LS-10939 and LS-10947) all in vegetative condition, one collection with an immature inflorescence (Bécquer HFC-81648), and three collections with immature to nearly mature fruits (Álvarez et al. HFC-63987, Bécquer HFC-83882, Lippold \& Gónzalez HFC-18852).

This species was included within Miconia sect. Chaenopleura largely on the basis of a phylogenetic analysis based upon ITS sequences (Judd 2007) using DNA from the voucher specimen Bécquer HFC-81648. The flowers of the recent collection, Michelangeli et al. 2226, display all of the putative floral synapomorphies of the West Indian clade of sect. Chaenopleura, i.e., a radially symmetrical androecium with the stamens flexed back 
and the anthers held more or less erectly, with white filaments, and white, obovate anthers that open by two longitudinal slits (Fig. 1). These morphological characters, therefore, confirm the placement of this species in sect. Chaenopleura.

The availability of fertile material allows for an assessment of the possible placement of this species within the diverse array of species of this section. The presence of dendritic hairs, nodes with prominently thickened lenticels, and bullate leaves with often cordate bases and the primary to quaternary veins conspicuously raised on the abaxial surface (Fig. 1) all suggest a placement in the bullate-leaved clade (see Judd 2007), which includes species such as M. favosa (Desr.) Naudin, M. howardiana Judd, Salzman \& Skean, M. sintenisii Cogn., and M. xenotricha Urb. \& Ekman. The floral morphology of Miconia turquinensis does not contradict this placement. If this taxonomic position is correct, Miconia turquinensis would be the only Cuban species in this group (among the array of species included in Judd 2007). We note, however, that the evidence for the monophyly of this group is based solely on morphology, and a recent DNA-based analysis suggests that it may not be a clade (Judd et al. 2015c), although subclade-level resolution is somewhat limited in parts of the tree.

Michelangeli et al. 2226 also allows us to significantly improve the description of Miconia turquinensis by the inclusion of numerous floral characters (following the descriptive format of Judd, 2007; see below). The flowers of Miconia turquinensis have the adaxial surface of the hypanthium 20-ridged, with ten major ridges alternating with ten minor ones. This condition also is seen in 14 other species of sect. Chaenopleura of the Greater Antilles (Judd 2007). Within the bullate-leaved clade such hypanthia also occur in M. howardiana, M. sintenisii, and M. xenotricha. Cuban species with such hypanthia include M. calycina Cogn., M. cubensis (C. Wright ex Griseb.) C. Wright, M. alternifolia (Griseb.) Alain, M. skeaniana Judd, and M. rufa (Griseb.) Triana.

In addition, Michelangeli et al. 2226 has stems that have multicellular, long-stalked hairs, each with a poorly developed glandular head (these hairs absent in prior collections of this species). Of course, this specimen also has the more conspicuous indumentum of ferrugineous, dendritic to elongate-dendritic and globular-stellate hairs. Long-stalked, gland-headed hairs also are known on the stems and/or hypanthia of several other species, e.g., M. barkeri Urb. \& Ekman and M. pseudorigida Proctor (in which such hairs are restricted to nodal regions), M. ferruginea (Desr.) DC., M. santanana Judd \& Skean, M. adenocalyx Urb. \& Ekman, and M. samanensis Urb. (with such hairs variable in occurrence - present or absent on stems, and also with or without such hairs on the hypanthia), or M. dielsiana Urb. (with gland-headed hairs on hypanthia, but not the stems). These long-stalked, gland-headed hairs must be variable in occurrence on the stems of M. turquinensis, as they were not seen on the stems of other collections of this species. Such variation is not surprising, however, as other species of sect. Chaenopleura, as noted above, are also variable in the development of such hairs. The Hispaniolan species M. multiglandulosa Cogn., of uncertain phylogenetic position within the section, always has such hairs on its stems, leaves, and hypanthia. It is also interesting that two species of the bullate-leaved clade have such hairs, i.e., M. sintenisii and M. pycnoneura Urb.

Finally, the young stems of Miconia turquinensis are quadrangular and have four well-developed longitudinal flanges (clearly shown on Michelangeli et al. 2226), a feature not previously noted (Judd 2007) although slightly flanged stems are seen also on the type (Ekman 14535). Flanged stems are rather unusual in sect. Chaenopleura, occurring in only five other species. Quadrangular stems with four flanges also occur in $M$. pteroclada Urb. and some populations of M. stenobotrys (L.C. Rich.) Naudin. The twigs of M. quadrangularis (Sw.) Naudin are square to rectangular in cross-section and are non-ridged or with four conspicuous to inconspicuous flanges. Stems with well-developed ridges are also characteristic of M. septentrionalis Judd \& R. Beaman and M. jimenezii Judd \& R. Beaman. However, all of these species are phenetically quite different from M. turquinensis in vegetative and floral features, and are not likely closely related (see Judd 2007). Only one of these, M. pteroclada, occurs in Cuba. However the rare and poorly known Cuban species, M. remotiflora Urb. (incl. M. acunae Borhidi), also of the Sierra Maestra (Urban 1923; Borhidi 1976), is phenetically quite similar to M. turquinensis in indumentum, inflorescence structure, and floral characters, and it also has quadrangular stems with four longitudinal flanges (see original description of both M. remotiflora and M. acunae, and type material of M. remotiflora: Cuba, Sierra Maestra, La Bayamesa, in cacumine montis humido, 1725 m, 4 May 1916, Ekman 7162, lectotype, designated here-S; and type material of M. acunae: Cuba, Sierra Maestra, Alto de 

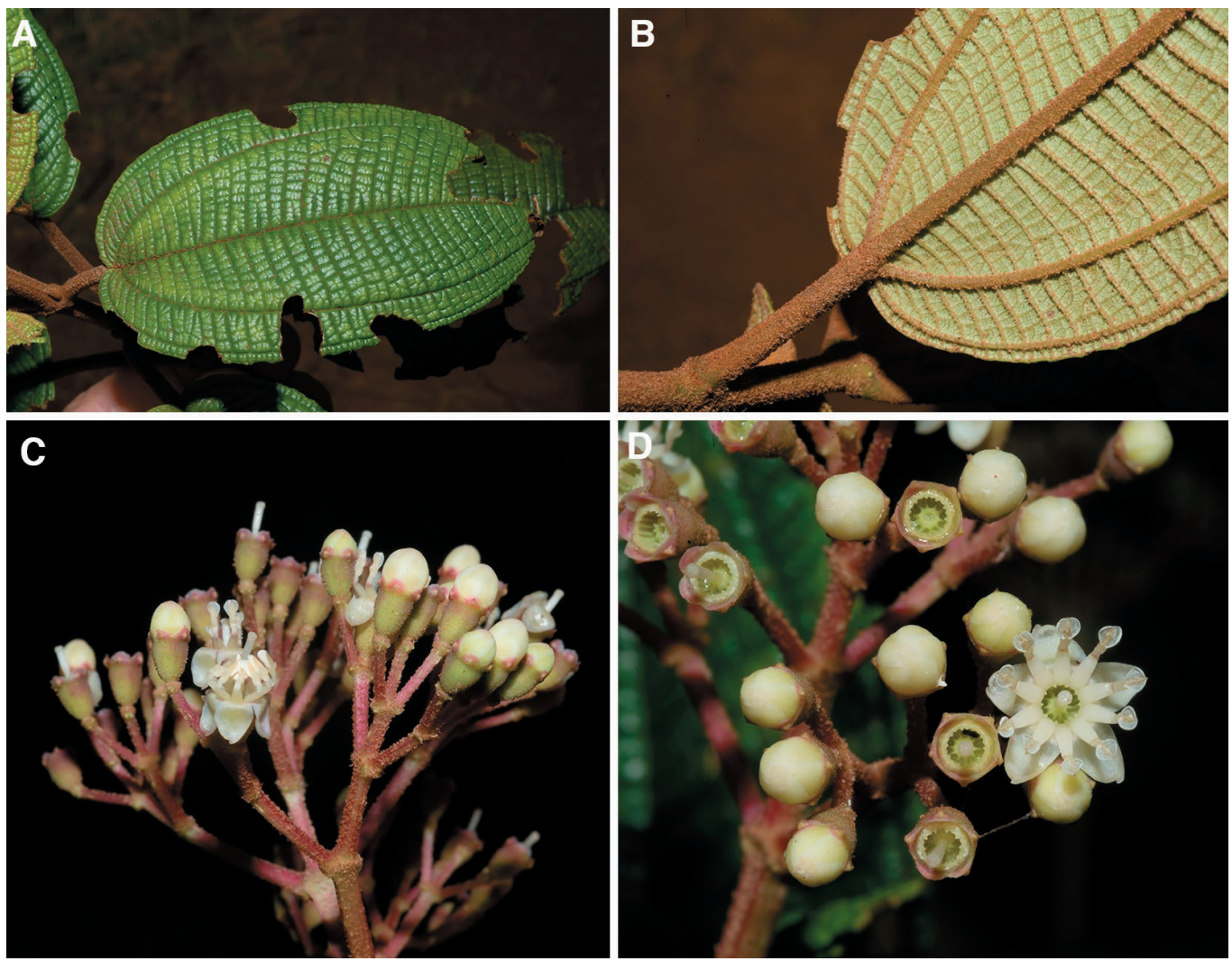

FIG. 1. Miconia turquinensis (Michelangeli et al. 2226): A, Leaf, adaxial surface; note bullate condition. B, Leaf, abaxial surface; note raised veins. C, Inflorescence and flowers. D, Flower, top view and very young fruits; note radial androecium and stamens opening by longitudinal slits, and also adaxially ridged hypanthia.

la Francia, Monte Uvero, 8 Feb 1971, Stuchlick \& Moncada SV-27233, holotype-HAC, isotype-HAC, Fig. 2; and an additional collection: Cuba, Sierra Maestra, Buey Arriba, Pico La Bayamesa, Álvarez et al. HFC-64378, HAJB). The two species are similar in most features, differing primarily in leaf size and shape (i.e, leaves with petiole $1-5 \mathrm{~cm}$ long, blade $4.5-15 \mathrm{~cm}$ long, 2.3-7.2 cm wide, with usually 6 secondary veins, and rounded to slightly cordate at base in M. turquinensis, and leaves with petiole $0.6-2.5 \mathrm{~cm}$ long, blade $3.5-11 \mathrm{~cm}$ long, $1.5-5 \mathrm{~cm}$ wide, with 4 secondary veins, and cuneate to obtuse at base in M. remotiflora) and in floral features (i.e, petals 3.7-4 mm long, style 4.5-5 mm long in M. turquinensis, and petals ca. $3 \mathrm{~mm}$ long, style ca. $4 \mathrm{~mm}$ long in M. remotiflora).

Miconia remotiflora (Urban 1923) is here, for the first time, considered to represent a species belonging to the West Indian clade of Miconia sect. Chaenopleura, and it unfortunately was not included in Judd (2007). We consider M. acunae (Borhidi 1976) to be conspecific with the earlier-described M. remotiflora because we can find no characters that differentiate it. This taxonomic placement within sect. Chaenopleura is supported by the similarity of M. remotiflora to M. turquinensis and by the form of its anthers; detailed descriptions of M. remotiflora can be found in Urban (1923) and Borhidi (1976). Miconia remotiflora likely is closely related to M. turquinensis, and the two are apparently geographically isolated. Both M. turquinensis and M. remotiflora, however, are rather poorly known, and a clearer understanding of their pattern of variation, differentiating characters, and phylogenetic placement (within the section) must await the collection of additional material. It is obvious that more field work in the Sierra Maestra, a region of high melastome diversity, is needed. 


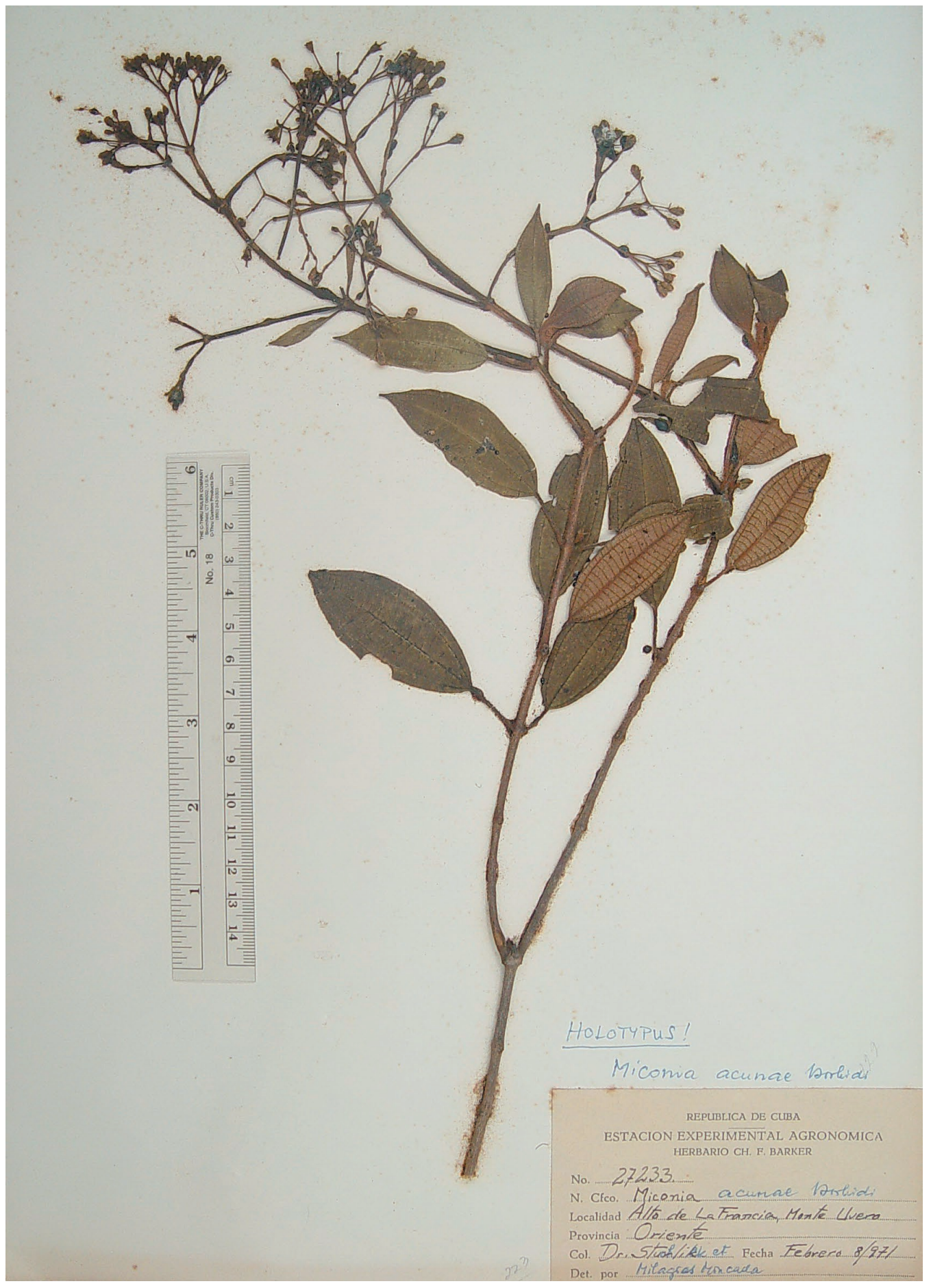

FIG. 2. Holotype of Miconia acunae (at HAC); note large inflorescence and rather small leaves, each with four secondary veins (two inconspicuous and intramarginal) and a cuneate or rounded base. 
TAXONOMIC TREATMENT

Miconia turquinensis Urb. \& Ekman, Repert. Spec. Nov. Regni Veg. 22:228. 1926. Tүре: Cuba. Oriente [Prov. Santiago de Cuba]: Sierra Maestra, at top of Pico Turquino, 2040 m, young inflorescence, 22-24 Jul 1922, E.L. Ekman 14535 (ноLотүPE: B, destroyed; LECTOTYPE, designated by Judd, 2007: S!).

Shrub or tree to $6 \mathrm{~m}$ tall. Indumentum of multicellular, ferrugineous, dendritic to elongate-dendritic or globular-stellate hairs, and minute globular hairs. Young twigs \pm rectangular in cross section, $2-5.3 \mathrm{~mm}$ wide, with 2 conspicuous to inconspicuous, longitudinal ridges on the broader faces, becoming \pm terete with age, the indumentum of moderate to dense dendritic to elongate-dendritic or globular-stellate, minute globular hairs, and sometimes also scattered, long-stalked, gland-headed hairs, somewhat glabrescent; internodes $1.3-7.5 \mathrm{~cm}$ long; prominent nodal lenticels present and placed in a stipular position. Leaves with petiole $1-5.5 \mathrm{~cm}$ long, the indumentum similar to that of twigs, but gland-headed hairs lacking; blade 4.5-15 cm long, 2.3-7.5 cm wide, ovate to elliptic, \pm flat, coriaceous, the apex acuminate to short-acuminate, the base rounded to slightly cordate, the margin plane distally and slightly revolute proximally, obscurely serrate to undulate-serrate (rarely strongly undulate-serrate) proximal $0-40 \%$ of margin entire or slightly undulate, the largest teeth to 0.4 (or 1.3 ) $\mathrm{mm}$ long, but often obscure, and margin merely undulate-serrate; venation acrodromous, \pm basal, with prominent midvein and usually 6 secondary veins, with 4 conspicuous secondary veins, the inner pair placed 3.5-14 mm in from margin, the outer pair placed $1-4 \mathrm{~mm}$ in from margin, and usually with 2 inconspicuous, intramarginal secondary veins, and numerous percurrent tertiary veins oriented subperpendicular to midvein, the tertiary veins connected by several percurrent quaternary veins, and the higher order veins orthogonal-reticulate; adaxial surface green, initially with ferrugineous, dendritic to elongate-dendritic hairs and minute globular hairs, but very quickly glabrescent, frequently with a few branched hairs and minute globular hairs persisting along midvein, the midvein, secondary, and tertiary veins strongly impressed, quaternary veins strongly to slightly impressed, and quinary and higher veins flat to slightly impressed, and the leaf thus bullate, the surface appearing minutely wrinkled when dry, with scattered druse crystals; abaxial leaf surface pale green, sparsely to moderately covered with ferrugineous, dendritic to elongate-dendritic hairs on primary to quaternary veins, the hairs to ca. $0.2 \mathrm{~mm}$ across and to $0.6 \mathrm{~mm}$ long, and the higher order veins and lamina with only scattered minute globular hairs, the primary and major secondary veins strongly raised, minor secondary and tertiary veins moderately raised, quaternary veins slightly raised, and higher order veins flat to very slightly raised. Inflorescences many-flowered, paniculate cymes of 2-4 major branch-pairs, 3-12 cm long, 2.2-16 cm in diameter; proximal segment of lowermost inflorescence branches $1.1-3.5 \mathrm{~cm}$ long, distal internodes increasingly shorter, ultimate branches very short, with indumentum similar to that of twigs, and each associated with a quickly caducous, oblong to narrowly ovate bract, 3-5 mm long, 0.5-1.3 mm wide, and the lowermost bractpair sometimes transitional to leaves; flowers in dichasia, each subtended by 2 caducous, narrowly ovate bracteoles, ca. 1.5-2.5 mm long, 0.3-0.7 mm wide, with acute apices. Flowers with pedicel 0-0.4 mm long. Hypanthium cylindrical, free portion 1.8-2.1 mm long, the outer surface with sparse to moderate ferrugineous, stellate-branched hairs, scattered minute globular hairs, the inner surface glabrous and 20-ridged, with 10 of these stronger and 10 weaker, the apices of the major ridges projecting to $0.2-0.3 \mathrm{~mm}$. Calyx teeth $5,0.5-0.6$ $\mathrm{mm}$ long, 1.7-1.9 mm wide, broadly triangular, with \pm acuminate apex; indumentum of sparse to moderate stellate-branched and minute globular hairs; calyx lobes 5, 0.7-1 mm long, 1.7-1.9 mm wide, ovate-triangular, reddish, with a few minute globular hairs or glabrous, but often with \pm stellate-branched hairs sparsely positioned along margin, the apex \pm obtuse to rounded, the margin entire, but sometimes with a few irregular notches; calyx tube $0.4-0.5 \mathrm{~mm}$ long. Petals $5,3.7-4 \mathrm{~mm}$ long, $2.1-3 \mathrm{~mm}$ wide, broadly ovate to elliptic, glabrous, white, with apex emarginate, with an asymmetrically located notch. Stamens 10 , geniculate, radially arranged with the filaments flexed back and the anthers held \pm erectly, white; proximal segment 2-2.4 mm long, glabrous; distal segment (including anther) 2.8-3 mm long, with minute dorsal, upward pointing projection to $0.3 \mathrm{~mm}$ long, the anther obovate, $2-2.5 \mathrm{~mm}$ long, with fertile portion of anther sacs $1.3-1.7 \mathrm{~mm}$ long, opening by 2 longitudinal slits, the connective/distal part of the filament extending $0.5-0.7 \mathrm{~mm}$ beyond the base of anther sacs. Ovary 3-loculate, ca. 2/3-inferior (and upper portion sterile), 2.7-3 mm long, 2.4-2.6 mm 
in diameter, short-ovoid, glabrous and ridged, with fluted apical projections to ca. $0.6 \mathrm{~mm}$ encircling the base of style; style 4.5-5 mm long; stigma \pm truncate. Berries 4-6 mm long, 4-6 mm in diameter, \pm globose, reddish when immature, but pale blue at maturity. (Fig. 1.)

Phenology.-Collected with immature inflorescences in July and November and in full bloom in November; fruits recorded in March, May and July. Probably blooming for an extended period.

Distribution.-Cuba, Sierra Maestra, in the vicinity of Pico Turquino and the mountains north of this peak; cloud forests and subalpine thickets; 1500-1974 m. Growing with Miconia rufa and M. skeaniana, from which M. turquinensis can be easily distinguished by its quadrangular and 4-flanged (vs. more or less terete) branches.

Specimens examined: CUBA. Prov. Granma: Buey Arriba, Pico La Botella, 1500 m, 11 May 1988, A. Álvarez et al. HFC-63987 (HAJB). Prov. Santiago de Cuba: Guamá, trail between Pico Joaquín and Pico Turquino, 1800-1900 m, 19 Nov 2003, E.R. Bécquer HFC-81648 (FLAS, HAJB); camino entre el Mirador de la Sabina y la cima del Turquino, 1900-1974 m, 26-27 Mar 2006, E.R. Bécquer HFC-83882 (HAJB); Sierra Maestra, Pico Cuba, entre el campamento y el Paso de las Angustias, 1800-1900 m, 11 May 1971, J. Bisse \& H. Lippold HFC-18862 (HAJB); slopes of Pico Turquino, E.L. Ekman 5479 (S, digital image seen); Sierra Maestra, on the northern spur of Pico Turquino, E.L. Ekman 14485 (NY, S, digital image seen); Pico Turquino, 20 Jul 1922, E.L. Ekman s.n. (NY); near summit of Pico Turquino, Bro. León LS-10939 (GH, NY) ibid., Jul 1922, Bro. León LS-10947 (IJ); Pico Turquino, cima, 11 May 1971, H. Lippold \& L. Gónzalez HFC-18852 (HAJB); Guamá, Parque Nacional Turquino, sendero Alto el Naranjo - Pico Turquino, 100-200 m de la cumbre del Pico Turquino, 1959' 25” N, 76 50' $08^{\prime \prime}$ W, 1950 m, 9 Nov 2013, F.A. Michelangeli 2226 with E.R. Bécquer, W. Carmenate, J.L. Gómez \& D. Vieltre (HAJB, NY).

It is perhaps surprising that this Antillean species was not until recently collected in flowering condition, as the Greater Antilles are considered to be well collected. However, this situation is not that uncommon in Melastomataceae, e.g., flowers are still unknown for the recently described Miconia cineana Majure, Judd, Ionta, \& Skean (Majure et al. 2014), Miconia abscondita Majure, Judd, \& Skean (Judd et al. 2015d), and Miconia pagnolensis Majure \& Judd (Majure et al. 2016). All are rare endemics of the Massif de la Hotte, Haiti, for which we have both DNA sequence data and vegetative morphological data. In addition, flowering material was only recently collected for Miconia alainii Judd \& Skean (Judd et al. 2015a), and flowers and fruits of Calycogonium rhomboideum Urb. \& Ekman also were unknown until about a year ago (Judd et al. 2015b). Our knowledge of the floral characters of Mecranium obtusifolium Cogn., a species that perhaps is sister to the remaining species of the Mecranium clade (Judd et al. 2015d), is based upon several buds and a single old flower lacking petals (Skean 1993). Finally, flowering material of Henriettea ciliata (Urb. \& Ekman) Alain, Mecranium plicatum Urb., Miconia abeggii Urb. \& Ekman, and the enigmatic Ossaea rubrinervis Urb. \& Ekman (Skean 1993; Liogier 2000) is still unknown.

\section{ACKNOWLEDGMENTS}

We thank Fabian Michelangeli for allowing the use of his beautiful photos based on plants in the population from which Michelangeli et al. 2226 was made (Fig. 1). This work was supported by a grant from the National Science Foundation (BSR-0818399). We also thank J. Dan Skean and an anonymous reviewer for their helpful comments on this paper.

\section{REFERENCES}

BoRHIDI, A. 1976 [1977]. Melastomataceas nuevas Cubanas. Abstracta Botanica operum ex Instituto taxonomiaeOikologiae Plantarum 4:23-32.

Judd, W.S. 2007. Revision of Miconia sect. Chaenopleura (Miconieae, Melastomataceae) in the Greater Antilles. Syst. Bot. Monogr. 81:1-235.

Judd, W.S., T. Clase, \& L.C. Majure. 2015a. First collection of Miconia alainii (Melastomataceae: Miconieae) with flowers. J. Bot. Res. Inst. Texas 9:449-451.

Judd, W.S., T. Clase, J.D. Skean, JR., \& L.C. Majure. 2015b. Noteworthy collections. Haiti and the Dominican Republic. Castanea 80:218-221. DOI: 10.2179/15-063.

Judd, W.S., L.C. MaJure, G.M. IOnTA, \& K.M. NeubiG. 2015c. Taxonomic studies in the Miconieae (Melastomataceae). XIII. Systematics of Miconia subcompressa, a Hispaniolan endemic comprised of three eco-geographic subspecies. Phytotaxa 197:61-83. DOI: 10.11646/Phytotaxa.197.2.1. 
Judd, W.S., L.C. MaJure, J.D. SkEAN, JR., \& K.M. NeubIG. 2015d. Miconia abscondita (Melastomataceae: Miconieae), a new species from the Massif de la Hotte, Haiti: Rediscovered in herbaria after being hidden for nearly nine decades. Rhodora 117:317-341. DOI: 10.3119/14-13.

LIoGIer, A.H. 2000. Melastomataceae. La Flora de La Española Vol. IX. Jardín Botánico Nacional “Dr. Rafael Ma. Moscoso,” Instituto Tecnológico de Santo Domingo (INTEC), Santo Domingo, República Dominicana.

Majure, L.C., W.S. Judd, G.M. IontA, J.D. SkeAn, JR., E.R. BéCquer, \& K.M. NeubiG. 2014. Miconia cineana (Melastomataceae: Miconieae), a new species from the Massif de la Hotte, Haiti, based on morphological and molecular evidence. Syst. Bot. 39:906-914. DOI: 10.1600/036364414X682247.

MAJuRe, L.C., E.R. BéCQuer, \& W.S. JudD. 2016. Revision of the Lima clade (Miconia sect. Lima, Miconieae, Melastomataceae) of the Greater Antilles. PhytoKeys 72:1-99. DOI: 10.3897/phytokeys.72.9335.

SkEAN, J.D., JR. 1993. Monograph of Mecranium (Melastomataceae-Miconieae). Syst. Bot. Monogr. 39:1-116.

URBAN, I. 1923. Melastomataceae (in Plantae cubenses Ekman I). Symb. Antill. 9 (1):111-127.

URBAN, I. 1926. Sertum Antillanum XXVI. Repert. Spec. Nov. Regni Veg. 22:222-241. 